\title{
Lycodes adolfi Nielsen \& Fosså, 1993 (Teleostei: Zoarcidae) recorded near Jan Mayen and in the eastern part of the Norwegian Sea
}

\author{
Ingvar Byrkjedal, Torleiv Brattegard and Peter Rask Møller
}

\begin{abstract}
Byrkjedal I., Brattegard T. and Møller P.R. 2009. Lycodes adolfi Nielsen \& Fosså, 1993 (Teleostei: Zoarcidae) recorded near Jan Mayen and in the eastern part of the Norwegian Sea. Fauna norvegica 28: $1-3$.
\end{abstract}

Specimens of Lycodes adolfi were collected from an epibenthic sampler at six stations near Jan Mayen and in the eastern part of the Norwegian Sea. The stations were at depths from 708 to $2150 \mathrm{~m}$ and all of them had subzero water temperatures. The records substantially increase the known distribution of this cold-water eelpout, previously known only from waters near Greenland.

Keywords: Zoarcidae, Lycodes adolfi, distribution, morphology

Ingvar Byrkjedal, Bergen Museum, University of Bergen, Muséplass 3, NO-5007 Bergen, Norway. Torleiv Brattegard, Marine Biological Station, University of Bergen, Espelandsveien 232, NO-5258 Blomsterdalen, Norway.

Peter Rask Møller, Zoological Museum, University of Copenhagen, Universitetsparken 15, DK-2100 Copenhagen Ø, Denmark

Corresponding author: Ingvar Byrkjedal, E-mail: ingvar.byrkjedal@zmb.uib.no

\section{INTRODUCTION}

The fairly recently discovered eelpout Lycodes adolfi Nielsen \& Fosså, 1993, has been known from Baffin Bay and East Greenland waters between $67^{\circ} 34^{\prime}$ and $73^{\circ} 54^{\prime} \mathrm{N}$, depth 386 1880 m (Nielsen \& Fosså 1993, Treble et al. 2000, Møller \& Gravlund 2003, Chambers and Dick 2007). On the Baffin Bay continental slopes $L$. adolfi is not rare and it was found to be a secondary indicator species for the deepest recognized fish fauna assemblage in the Bay (Jørgensen et al. 2005). It is not found in southern Greenland waters (Møller \& Jørgensen 2000) and it is likely that the east and west Greenland specimens are isolated from each other, due to shallow waters in the north and warm water in the south.
Benthic invertebrate sampling in the western and eastern parts of the Norwegian Sea yielded several specimens of this eelpout, extending its known distribution considerably. The present note reports the new records and briefly discusses the distribution of the species. Being a little studied species, we also summarize some meristic and morphometric data for the specimens.

\section{MATERIAL AND METHODS}

The samples of eelpouts were taken during cruises with $\mathrm{R} / \mathrm{V}$ "Håkon Mosby" (University of Bergen) in 1983 (cruise 13-83) and 1986 (cruises 16-86 and 20-86). The cruises were carried out primarily to study the composition of the hyperbenthic invertebrate fauna of the deeper parts of the Norwegian Sea. 
The sampling gear that yielded eelpouts was a Rothlisberg \& Pearcy (RP) epibenthic sampler (Rothlisberg \& Pearcy 1977, Buhl-Jensen 1986, Brattegard \& Fosså 1991) with a net of 0.5 $\mathrm{mm}$ mesh size.

Temperature measurements of near-bottom water were made using a Neil Brown III CTD. The material was elutriated in liberal amounts of sea water and strained in a set of sieves. The eelpouts were handpicked from the sieves and fixed in buffered $4 \%$ formaldehyde-seawater solution and later transferred to $70 \%$ ethanol for permanent storage in the vertebrate collections at Bergen Museum. The fishes were examined and measured after preservation, generally following the methods of Anderson (1994). The specimens were radiographed, and vertebrae, dorsal and anal fin rays were counted from radiograph images.

\section{RESULTS}

The material contained seven individuals of $L$. adolfi from six stations (Table 1), two of which were from waters near the island Jan Mayen, one on the Jan Mayen Ridge, two northeast of the Faroes, and one on the Vøring Plateau (Figure 1). The specimens were caught on the continental slopes, at depths between 708 and $2150 \mathrm{~m}$, all of them in subzero water temperatures (between -0.3 and $-0.9^{\circ} \mathrm{C}$ ).

The specimens had a standard length $\left(\mathrm{S}_{L}\right)$ of $38-127 \mathrm{~mm}$, a preanal length of $35.9-40.5 \%$ of $\mathrm{S}_{L}$, and a body depth at anus

Table I. Station informations for the new specimens of L. adolfi. Bergen Museum catalogue numbers are given under the acronym ZMUB.

\begin{tabular}{ccccc}
\hline ZMUB & Date & Position & Depth (m) & Temp $\left({ }^{\circ} \mathrm{C}\right)$ \\
\hline 15661 & 27 July 1986 & $70^{\circ} 41^{\prime} \mathrm{N}-7^{\circ} 38^{\prime} \mathrm{W}$ & 1243 & -0.6 \\
15659 & 25 July 1986 & $69^{\circ} 01^{\prime} \mathrm{N}-8^{\circ} 25^{\prime} \mathrm{W}$ & 879 & -0.6 \\
15660 & 27 July 1986 & $70^{\circ} 49^{\prime} \mathrm{N}-9^{\circ} 44^{\prime} \mathrm{W}$ & 886 & -0.6 \\
16095,16096 & 17 August 1986 & $63^{\circ} 35^{\prime} \mathrm{N}-0^{\circ} 06^{\prime} \mathrm{W}$ & 2150 & -0.9 \\
15667 & 2 June 1983 & $62^{\circ} 12^{\prime} \mathrm{N}-0^{\circ} 00^{\prime} \mathrm{W}$ & 708 & -0.3 \\
15657 & 30 July 1986 & $67^{\circ} 55^{\prime} \mathrm{N}-2^{\circ} 26^{\prime} \mathrm{E}$ & 1698 & -0.9 \\
\hline
\end{tabular}

of 6.4-8.4\% of $\mathrm{S}_{L}$ (Table 2). The three largest specimens $\left(\mathrm{S}_{L}\right.$ $111-127 \mathrm{~mm}$ ) had a maximum of 17-20 scale rows between the dorsal and anal fins and a distance from the snout to the anterior scales of 43.6-52.0\% of $\mathrm{S}_{L}$, whereas the four smaller ones $\left(38-50 \mathrm{~mm} \mathrm{~S}_{L}\right)$ had only scattered scales in the midlateral region of the tail. All the specimens were uniformly brown with a dark (blackish) peritoneum; none showed any indication of transverse bands or other pigment patterns of the integument. Lateral lines were difficult to observe, but a single lateral line was found in the largest specimens. The operculum showed a pronounced pointed tip, and the pectoral fins almost reached anus (Figure 2).

\section{DISCUSSION}

The records show that the species is not restricted to continental slope waters near Greenland. While the occurrence near Jan Mayen might not be surprising as an extension along the ridge systems from the Greenland range at the same latitude, the records on the eastern side of the Norwegian Sea indicate a much larger distribution of this species than formerly reported. Previous as well as present records show L. adolfi

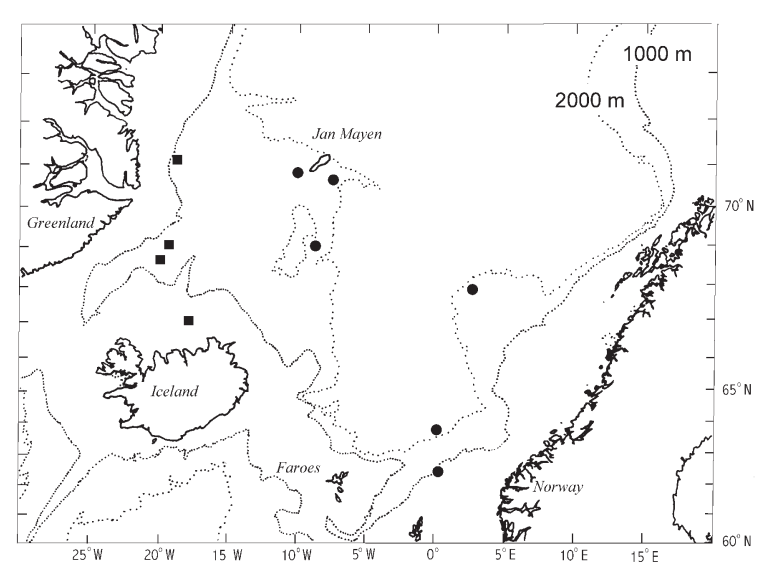

Figure I. Localities at which Lycodes adolfi has been caught in the Nordic Seas. Squares denote previously known occurrences (from Nielsen \& Fosså 1993), circles show new records.

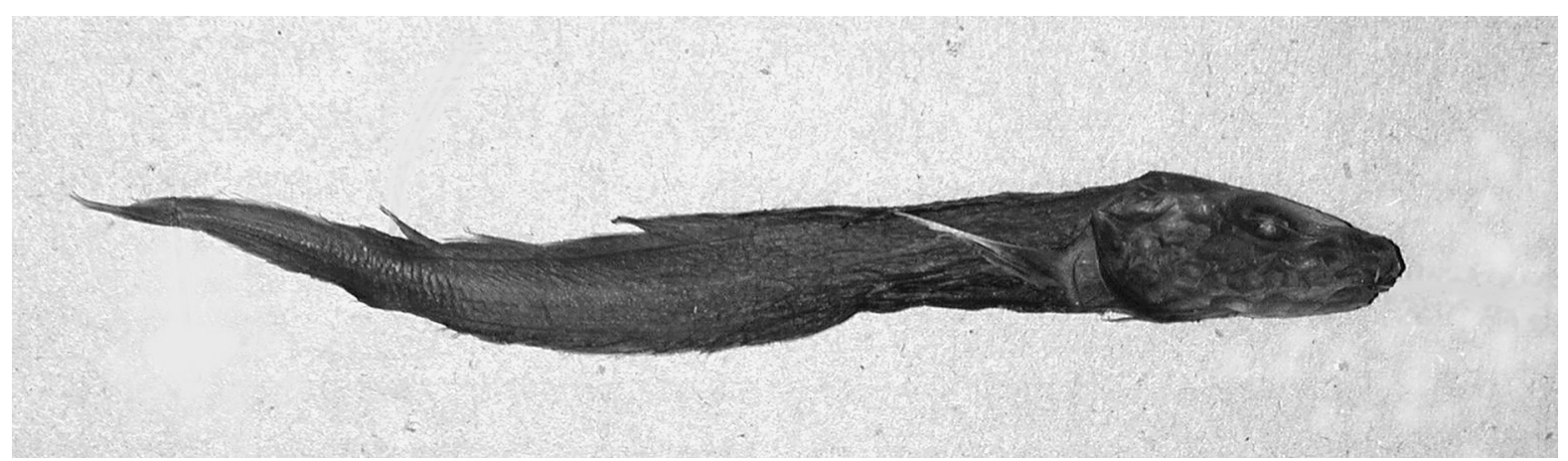

Figure 2. Lycodes adolfi, specimen ZMUB 15661; $\mathrm{S}_{L} 127 \mathrm{~mm}$. 
Table 2. Meristic and morphometric characters of the new specimens of Lycodes adolfi $(\mathrm{n}=7)$ caught in the Norwegian Sea.

\begin{tabular}{lccc}
\hline Characters & Average & SD & Range \\
\hline Standard length (mm) & 75.4 & 40.5944 & $38.2-127$ \\
Meristic characters: & & & \\
$\quad$ Dorsal fin rays & 96.0 & 3.2950 & $92-101$ \\
$\quad$ Anal fin rays & 81.7 & 3.8065 & $77-87$ \\
$\quad$ Pectoral fin rays & 17.3 & 0.4900 & $17-18$ \\
Anal fin origin below dorsal fin ray no. & 16.0 & 1.0000 & $14-17$ \\
Total vertebrae & 102.1 & 3.2701 & $98-106$ \\
$\quad$ Precaudal vertebrae & 20.3 & 0.6999 & $19-21$ \\
Teeth on vomer & 6.6 & 0.9820 & $2-5$ \\
Morphometric characters as \% of $\mathrm{S}_{\mathrm{L}}:$ & & & \\
Head length & 22.2 & 1.5450 & $19.7-24.2$ \\
Preanal length & 38.6 & 1.8046 & $35.9-40.5$ \\
Predorsal length & 26.4 & 1.8435 & $22.6-28.3$ \\
Snout length & 6.0 & 1.0641 & $4.5-7.3$ \\
Depth at anus & 7.6 & 0.7947 & $6.4-8.4$ \\
Pectoral fin length & 15.9 & 1.3100 & $13.7-17.3$ \\
Pelvic fin length & 4.3 & 0.5500 & $3.5-5.2$ \\
\hline
\end{tabular}

to be a cold-water species found in water temperatures below (or just above) $0^{\circ} \mathrm{C}$ and at fairly great depth, usually more than 1000 m (Nielsen \& Fosså 1993, Møller \& Jørgensen 2000). The Norwegian Sea basin has subzero temperatures at depths below 600-700 $\mathrm{m}$ due to Arctic water branching from the East Greenland Current (Blindheim 2004), and thus, conditions for this species possibly exist in the deep basin as well as along larger parts of its surrounding continental slopes. Zoarcids form an important part of the deep-sea cold-water fish communities along the slope of the eastern Norwegian Sea; from 17 trawl stations Bergstad et al. (1999) recorded 11 zoarcid species, of which only two were associated with the warmer Atlantic Water found along the shelf edge. The dominant species in the deep central part of the Norwegian Sea is L. frigidus Collett, 1879. Lycodes adolfi and L. frigidus are similar in many characters, and scaleless juveniles less than $100 \mathrm{~mm}$ of the two species are difficult to separate. Lycodes adolfi differs by having fewer pectoral fin rays (16-19 versus 19-23) and precaudal vertebrae (19-21 versus 21-24) (Møller unpublished data).

The present material consisted of small (juvenile) specimens (3-13 cm). Møller \& Jørgensen (2000) found no sexually mature specimens within the size range of $7-18 \mathrm{~cm}$ that they examined from West Greenland, while Nielsen \& Fosså (1993), who examined specimens up to $23 \mathrm{~cm}$, found several that were sexually mature. Morphologically the specimens are well in accordance with the diagnosis given by Nielsen \& Fosså (1993): restricted squamation, pointed opercular tip, one lateral line, preanal length less than $45 \%$ of the $\mathrm{S}_{L}$, depth at anus less than $10 \%$ of the $S_{L}$, pectoral fin rays $17-18$, less than 25 scale rows between dorsal and anal fins, pectoral fin almost reaching anus, and plain colour.

\section{ACKNOWLEDGEMENTS}

We would like to thank professor H. Haflidason for giving us access to the radiograph at the Department of Earth Science, University of Bergen. We are also grateful to two anonymous reviewers for their comments on our manuscript.

\section{REFERENCES}

Anderson, ME. 1994. Systematics and osteology of the Zoarcidae (Teleostei: Perciformes). Ichtyological Bulletin of the J.L.B. Smith Institute of Ichtyology 60: 1-120.

Bergstad OA, Bjelland O, Gordon JDM 1999. Fish communities on the slope of the eastern Norwegian Sea. Sarsia 84: 67-78.

Blindheim J. 2004. Oceanography and climate. Pp. 65-96 in Skjoldal HR (ed.). The Norwegian Sea Ecosystem. Tapir Academic Press, Trondheim.

Brattegard T, Fosså JH. 1991. Replicability of an epibenthic sampler. Journal of the Marine Biological Association of the United Kingdom. 71: 153-166.

Buhl-Jensen L.1986. The benthic amphipod fauna of the WestNorwegian continental shelf compared with the fauna of five adjacent fjords. Sarsia 71: 193-208.

Chambers CA, Dick TA. 2005. Trophic structure of one deepsea benthic fish community in the eastern Canadian Arctic: Application of Food, Parasites and Multivariate Analysis. Environmental Biology of Fishes 74: 365-378.

Jørgensen OA, Hvingel C, Møller PR, Treble M. 2005. Identification and mapping of bottom fish assemblages in Davis Strait and Southern Baffin Bay. Canadian Journal of Fisheries and Aquatic Sciences 62: 1833-1852.

Møller PR, Jørgensen OA. 2000. Distribution and abundance of eelpouts (Pisces, Zoarcidae) off West Greenland. Sarsia 85: 23-48.

Møller PR, Gravlund, P. 2003. Phylogeny of the eelpout genus Lycodes (Pisces, Zoarcidae) as inferred from mitochondrial cytochrome $\mathrm{b}$ and $12 \mathrm{~S}$ rDNA. Molecular Phylogentics and Evolution 26: 369-388.

Nielsen JG, Fosså SA. 1993. Lycodes adolfi, a new species of eelpout (Zoarcidae) from Greenland. Cybium 17: 39-44.

Rothlisberg PC, Pearcy WG. 1977. An epibenthic sampler used to study the ontogeny of the vertical migration of Pandalus jordani (Decapoda, Caridea). Fishery Bulletin, NOAA, US 74: 944-997.

Treble MA, Brodie WB, Bowering WR, Jørgensen OA. 2000. Analysis of data from trawl survey in NAFO Division 0A, 1999. North Atlantic Fisheries Organization SCR Doc. 00/31, Serial No. N4260: 1-19. 